\author{
VALKÓ Roland, \\ OLSOVSZKYNÉ NÉMEDI \\ Andrea \\ Kaposvári Egyetem, \\ Marketing és Kerskedelem Tanszék \\ (Kaposvár University, \\ Department of Marketing and Commerce) \\ H-7400 Kaposvár, Guba S. u. 40 . \\ e-mail: roland.valko23@gmail.com
}

\section{EGY MEGÚJULT SPAR SZUPERMARKET VÁSÁRLÓKRA GYAKOROLT HATÁSÁNAK VIZSGÁLATA}

\author{
STUDY OF THE EFFECT OF A RENEWED SPAR \\ SUPERMARKET ON ITS CUSTOMERS
}

\begin{abstract}
Nowadays, the existence of a business unit and the fact of the purchasing process are not enough by themselves to understand the consumers' behavior. Customers do not only have different preferences, but they are also critical, with higher and higher expectations. To understand all these, we carried out studies in the fully transformed SPAR supermarket in Kaposvár in 2016 and 2017 . Our aim was to come to know completely the effect that this renewed supermarket had on its customers. During the research the first pillars were to determine the main aspect of choosing a shop and customer satisfaction. We mapped every inch of the shop by observations based on predefined criteria. We were exposed to direct communication with numerous consumers that helped us to enlighten further the strong and weak points of the shop. The first impression and all the information coming from direct experience had a positive effect thanks to the reopening. When the business unit became more and more cognoscible, more and more difficulties and also positive experiences surfaced due to carrying out both purchasing process and specific researches as well. The observations supported the result of the survey because amongst 159 customers the closeness of the shop and the habit primarily dominated as the main factors when choosing a shop besides the nice and fresh appearance. After the formerly mentioned criteria there came the prices and the importance of the quality of the products, in different order. Concerning the modernized supermarket, customers expressed either their satisfaction and loyalty or their dissatisfaction. However, by applying the Homburg-Stock employee satisfaction-loyalty matrix on the customers, we found that more than $80 \%$ of the respondents were satisfied with the shop and $40 \%$ of the consumers confirmed their loyalty. Still, in order to define the customer's loyalty towards a product or a shop to a certain degree, first the customer has to be satisfied and the satisfaction has to be maintained. Over time the expectation and longing subside, giving space to the routine and the monotonous circulation of customers that need to be resolved by the marketing tools of the supermarket.
\end{abstract}

Keywords: customer behavior, factors affecting store choice, customer satisfaction JEL-kód: $\mathrm{M}_{3} \mathrm{I}$

\section{BEVEZETÉS}

A 20I6-os év nyári időszakában több hónapra bezárta kapuit vásárlói előtt, majd szeptember I-én nyitott ki újra a Kaposvár, Honvéd utca 57. szám alatt található SPAR szupermarket. A teljeskörűen átalakított, új üzlet új ingereket vált ki a vásárlókból, egyúttal a megújult SPAR szupermarket vásárlókra gyakorolt hatása ismeretlen, így a kutatás tükrében olyan következtetéseket és javaslatokat fogalmaztunk meg, amelyeket konkrét SPAR-vásárlói vélemények támasztanak alá, $\mathrm{s}$ amelyeket a SPAR cégcsoport is hasznosítani tud.
Jelen tanulmányban a kutatás két pillérét mutatjuk be, egyrészről az üzletválasztást befolyásoló tényezőket, továbbá a vevői elégedettséget. A többi vizsgált tényező - mint a vásárlói magatartás és döntéshozatal, az in-store marketing, a boltimarketing-aktivitások - elemzésére jelen tanulmány nem tér ki.

A célkitűzésekre vonatkozóan az első feltevésünk, hogy az üzletválasztási szempontok közül a vásárló számára a legfontosabb a kedvező ár-érték arány (HI). Földi (2008; 20I2) alapján az üzletválasztásra nagy befolyással bír, hogy a kedvező árak mellé jó minőség társuljon. 
A második hipotézisünk szerint a vásárlók összességében elégedettek a SPAR szupermarkettel $\left(\mathrm{H}_{2}\right)$. Hiszen az elégedettség/elégedetlenség egy emocionális összegző válasz, személyes értékelés, amely fontos eleme a gazdasági sikernek (Bátor, 2007), jelen esetben a SPAR szupermarketnek is.

\section{I.I. AZ ÜZLETVÁLASZTÁST BEFOLYÁSOLÓ TÉNYEZŐK ÉS A VEVÖI ELÉGEDETTSÉG}

Az AC Nielsen Piackutató Kft, 20I6-os közlése szerint az élelmiszerüzletek kiválasztása, mérlegelése előtt elsődleges szemponttá vált, hogy az adott egység a vásárlónak élményt nyújtson. A magyar válaszadók több mint egyharmada azt vallja, hogy számára öröm az üzletben vásárolni az online fogyasztás helyett, tehát szeretnek boltba járni (Nielsen, 20I6).

Horváth (2010) megfogalmazza, hogy az üzletválasztás fontos alkotója vásárlási döntésünknek, mert ennek egy része az eladás helyén megy végbe. Gyakori esetnek tartja, hogy a kereskedelmi egység megválasztása megelőzi a márkaválasztást. Azonban nem hagyható figyelmen kívül a „vásárlási vadászmezo"” sem, hisz Töröcsik (2016) szerint szem elött kell tartani azt a tényt is, hogy társadalmunk nagy hányada igen szűk mozgástérrel rendelkezik a vásárlói döntéseket illetően. Földi (20I2) felhívja a figyelmet az üzletválasztással és fóként az azt befolyásoló tényezőkkel kapcsolatban arra, hogy az érintett szakemberek igen eltérő rangsorokat állítottak fel fontosságuk alapján. Miután disszertációjában összeveti megállapításaikat, kiderül, hogy a vásárlók üzletválasztásuk során a legfontosabbnak az üzlet helyét, méretét tartják, összefüggésben a megközelíthetőséggel és annak kényelmével. A sorban a második az imázs- és atmoszfératényezők, végül az árszínvonal és akciós árak. Továbbá vizsgálta az élelmiszer-vásárlást befolyásoló tényezők fontosságának változását 2000 és 20 I I között a fogyasztók körében, ahol 20I I-ben az első három helyet az áru frissessége és minősége, az árszínvonal és a választék foglalta el. A fogyasztókban - vásárlási tapasztalataik során - egyfajta minőségtudat alakul ki, amelyet az árakhoz társítanak (Kandikó, 2009).

Törőcsik az üzletértékeléshez kapcsolódó kritériumokat állított fel. Komplex hatásuk miatt azokat emeltük ki ezekből, amelyek a primer vizsgálataink megoldását elősegítik. A sorban az elsők a megjelenés, a külső bolti környezet és portál kialakítása, amelyek már sugallhatják a boltban uralkodó árszínvonalat (Törőcsik, I995). A külső környezetből az üzletbe lépve az eladótér tárul a vásárló elé (Gyenge, 2008). Földi (2012) megállapította, hogy a belső elrendezés nagy hatással van a vásárlók boltban eltöltött idejére, meghatározza, hogy milyen úton haladjanak, valamint hogy menynyi termékkel kerüljenek kapcsolatba, de természetesen hatással van arra is, hogy mit és mennyit vásárolnak. A termékröl alkotott fogyasztói véleményt legjobban az áru jelenléte, megjelenítése határozza meg. A fogyasztók szempontjából előnytelen a vizuális zürzavar, mert a vevő rosszul érzi magát és elégedetlen lesz. Ezekre megoldásként szolgál a kedvező polcelrendezési terv és az, hogy a fogyasztó a megszokott helyén találja, amit éppen keres (Székely, Sipos E Losó, 2009). Természetesen a választást, a boltban uralkodó légkört az adott üzlet személyzetének magatartása alapjaiban meghatározza. A dolgozókkal szembeni elvárások közé tartozik a külső megjelenésük, a tiszta formaruha, mely adott esetben a védjegyükké kell, hogy váljon (Töröcsik, I995).

A vásárlásoknak van egyfajta „utóéletük” a termék megszerzése vagy az általánosságban vett fogyasztással kapcsolatos tapaszta- lások megélése során, amely az elégedettség (pozitív) vagy az elégedetlenség (negatív) érzése (Töröcsik, 2007; Agárdi, 2010). A szakirodalomban a szerzők általában a termékkel kapcsolatos elégedettséget veszik górcső alá, de úgy gondoljuk, hogy megállapításaik egy adott üzlet körülményeire vonatkozóan ugyanúgy érvényesek lehetnek. Bátor (2007) értekezésében kifejti, hogy sem a hazai, sem a nemzetközi szakirodalomban nincs egységes fogalmi meghatározás. Emellett hangsúlyozza, hogy az egyén aktuális hangulata is alapvetően meghatározó tényező, továbbá kulcsfontosságú a vállalat sikerében.

A Földi (20I2) által leírtak alapján megállapítható, hogy az elégedettség tágabb értelemben a fogyasztói magatartás fogalmának középpontja, szükebb értelemben az üzletválasztási szempontok közé sorolva a kiskereskedelmi szolgáltatásokkal kapcsolatos. Kenesei (2017) elégedettségi vizsgálatában kiemeli az interakciós igazságosságot is, amely a bánásmódra vonatkozik, arra, hogy a fogyasztóval szemben támasztott eladói magatartás (kedvesség, udvariasság stb.) megfelelő volt-e. Bár Bohnné szerint az általában vett elégedett vevő nem létezik, mert ami a mai napon megfelelt a vásárlónak, az már nem biztos, hogy a következő napon is elegendő, megfelelő lesz. Kihangsúlyozza, hogy nem feltétlen az ár, hanem az ár és a minőség, a vevők igényeinek az összhangja a meghatározó (Bohnné, 2012). Bohnné, (2005; 2009) elégedettségi szint alapján három vevőtípust különböztet meg, aki lehet csalódott, elégedett és lenyűgözött. Így a csalódott egyén a vállalkozással való találkozást rendkívül kellemetlen élményként éli meg. Az elégedett ügyfél vásárlásai során prioritást élvez a cég, hatása pozitív és megnyugtató. A lenyügözött vásárló az, aki valamilyen formában történő, várakozásait felülmúló - pozitív - többletkiszolgálást kapott, és többnyire ez a vevőtípus válik lojálissá a vállalat iránt.

Rudolfné (2015) az elégedettség és a lojalitás összefüggéseit a szolgáltató szektorban - vendéglátásban - vizsgálta. Meghatározta a négy releváns egyéni vevői viselkedésmintát, amelyek a lojalista vagy apostol, elpártoló vagy terrorista, a zsoldos és a túsz. A lojalista hűséges és nem pártol el a cégtől, ezzel szemben a terrorista másokat is meggyőz arról, hogy váltsanak. A zsoldos elégedett, bár alacsony az elkötelezettsége, míg a túsz nem tud váltani.

Ha márka, üzlet szempontjából vizsgáljuk az előbbieket, akkor hasonló lesz a végkimenetel. Székely, Sipos és Losó (2009) a megelégedettség-lojalitás mátrixban tipizál. Ebben a keretben nagyfokú elkötelezettséggel és újravásárlási aránnyal a hüséges, lojális vevők jellemezhetők. A túszoknál az álhüség dominál. Esetükben az elégedettség alacsony, az újravásárlás mértéke azért magas, mert belenyugodnak helyzetükbe, elfogadják a jelenlegi bolt kínálatát, amíg nem találnak jobbat. A kedvezménykeresők csak időnként vásárolnak az adott helyen, ezért lojalitásuk alacsony, viszont a megvásároltakkal rendkívül elégedettek. Végül az éppen „beeső vásárlók”, aki nem térnek vissza az üzletbe, nem tartják lényegesnek választásukban a márkahűséget, ebből következően elégedettségük, vásárlási gyakoriságuk is alacsony.

Aswad (2012) megjegyzi, hogy a Homburg-Stock-féle dolgozói elégedettség és lojalitás mátrix némi változtatással a vásárlókra szintén alkalmazható. Ennek alapján az első csoportba a „racionálisegyüttműködő" vevőket sorolja, akik tartós partnerként játszanak szerepet a szervezet életében. Az,„alkalomszerü” vásárlónak magas az elégedettsége, bár hüsége alacsony az általában egyszeri vételből fakadóan. A „kényszerü” fogyasztóknál a lojalitás magas, viszont az elégedettség alacsony, míg a problémás vevőkre a lojalitás és elégedettség alacsony szintje jellemző. Megállapítható, hogy a 
vállalatnak értéket kell közvetítenie vásárlói felé, azonban ehhez elengedhetetlen a szervezeti kultúra és a képességek folyamatos megerősítése. Hoffmeister-Tóth, Simon és Sajtos (2003) szerint - a fentieket összefoglalva - azonban egy biztos, hogy akármilyen is legyen a vásárlás kimenetele, lesznek elégedett és kevésbé elégedett vásárlók. A fogyasztó vélhetően emlékezni fog legutóbbi vásárlásának elégedettségi szintjére, amely egy következő, hasonló vétel esetén nagymértékben befolyásolja döntését.

\section{ANYAG ÉS MÓDSZER}

A téma szekunder forrásainak megismeréséhez többnyire a hazai publikációkat tartottuk szem elött, valamint az Ipsos Média-, Reklám-, Piac- és Véleménykutató Zrt., a GfK Hungária Piackutató Intézet, és az AC Nielsen Piackutató Kft. közléseit használtuk fel.

Primer vizsgálatainkban a megfigyelés és a megkérdezés módszereit alkalmaztuk.

Strukturált megfigyelést végeztünk, melynek nagy előnye, hogy növeli az adatok, eredmények megbízhatóságát. A mintavétel önkényes, választásunk a Kaposvár, Honvéd utca 57. szám alatt található SPAR szupermarketre esett, amelyről az üzletvezetővel előzetes egyeztetés nem történt, a még reálisabb információk elérése érdekében. Kizárólagos megfigyelőként voltunk jelen (Lehota, 200I). A megfigyelési íven szereplő adatok elemzését szöveges formában végeztük, amelyek kiegészítő jelleggel bírnak.

A kérdőíves megkérdezésre 2016 telén, december 2. és december I5. között került sor. A minta alapsokaságát azok a fogyasztók képezték, akik az előre meghatározott napokon az adott szupermarketbe betértek. A mintasokaság meghatározása véletlenszerüen, egyszerü mintavétellel történt, vagyis minden egyes elemnek ugyanakkora volt az esélye bekerülni a mintába, tehát a véletlenszerüséget a vásárlók önkéntes kérdőívkitöltése jelentette (Kotler E Keller, 20I2; Lehota, 200I). A strukturált kérdőív típusát tekintve írásbeli jellegü, önkitöltő, nyomtatott formátumú. A két A4-es oldal terjedelemben fóképp zárt kérdéseket alkalmaztunk (Veres, Hoffmann E Kozák, 2006). A válaszadás önkéntes és anonim volt (Lehota, 200I). A terepmunka szervezésében előnyt jelentett, hogy a szupermarketben végezhettük el a felmérést, valamint az üzletben elhelyezett óriásplakáttal hívtuk fel a figyelmet arra. Ez az írásban történő empirikus kutatási módszer, „gyüjtődoboz" -eljárás segítségével ment végbe (Molnár, 2010), vagyis miután a vásárlók távozásukkor kitöltötték a kérdőíveket, egy erre a célra kihelyezett, lezárt dobozba dobhatták válaszaikat. A kérdőívek feldolgozása matematikai-statisztikai programok használatával (PSPP és Excel) valósult meg. Gyakorisági eloszlásokat számoltunk, valamint szignifikanciavizsgálatot végeztünk a háttérváltozók függvényében. Az elégedettség vizsgálatakor a Homburg-Stockféle elégedettség-lojalitás mátrixot (Aswad, 2012) alkalmaztuk.

\section{EREDMÉNYEK ÉS ÉRTÉKELÉSÜK}

A kérdőíves megkérdezés eredményeit I59 konkrét SPAR-vásárló alapján ismertetjük ábrák, táblázatok segítségével, amelyeket a megfigyelési eredményekkel egészítettünk ki dőlt betűs kiemeléssel.

Először arra kerestük a választ, hogy mi alapján választják az adott SPAR-üzletet a vásárlók. A választ adóknak lehetősége volt több okot is megjelölni az üzletválasztást befolyásoló tényezőkre vonatkozóan, de nem mindenki élt a többszörös választás lehetőségével. A kapott eredményeket az 1. ábra mutatja be.
I. ábra: Az üzletválasztást befolyásoló szempontok megoszlása

$$
(n=159)
$$

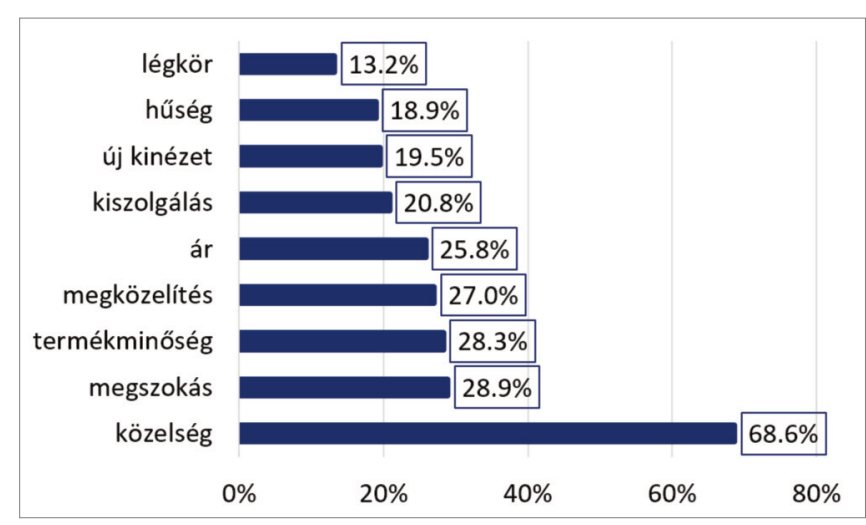

Földi (20I2) doktori értekezésében I9 üzletválasztási kritériumot határozott meg kérdőívében $(\mathrm{n}=640)$, illetve különbséget tett a napi és nagybevásárlás között. Mi nem tettünk különbséget vásárlás és vásárlás között, és csupán kilenc szempontot állítottunk fel. Földi Kata szerinti tényezők sorrendiségének első három helyét az áru frissessége és minősége, az árszínvonal és a választék foglalták el. Saját kutatásunkban, kifejezetten a SPAR szupermarketre vonatkozóan a harmadik helyet foglalja el a termékek minősége 28,3\%-kal, míg az árak a táblázat közepén helyezkednek el, fontosságuk így közepes mértékünek tekinthető.

Esetünkben a közelség, a bolt elhelyezkedése a mérvadó, amit a válaszadók közel 70\%-a kiemelt szempontnak vélt. A bolt új kinézete a megkérdezettek csupán 19,5\%-át befolyásolta a boltválasztásban. Megfigyeléseink is alátámasztják, hogy a SPAR-t körülvevő helyszínekről, beépítettségtől függetlenül, akár már 80-Ioo méterről is jól látható a szupermarket. Különböző közlekedési eszközökkel, de gyalogosan is könnyen elérhető üzletről van szó. A bejárat előtt megjelennek az aktuális ajánlatokra vonatkozó megállítótáblák (általában I-2), amelyek a termékekkel kapcsolatos akciókra, kedvezményekre utalnak. Megfigyeltük továbbá, hogy a termékek árai is változtak, a korábbi állapothoz képest felfelé ívelő tendenciát mutatnak, még a SPAR-család termékei esetében is. Az tapasztalható, hogy POS / POP „tömegekkel” lehet találkozni a SPAR szupermarketben. Főként a bal oldalon meghatározóak ezek, jól fellelhetők, de természetesen terméktől és aktuális stratégiától is függ a jelenlétük. A boltban, a belépést követően, a megállítótáblákon túl, a forgóvilla mellett balra akciós újságok vannak kihelyezve. Így a vásárlásokat több esetben a szóróanyag kíséri, amelyet a vevők menet közben átlapozhatnak. De a mennyezetről lelógó plakátok, poszterek is felhívják a figyelmet az aktuális ajánlatokra, akciókra, illetve az egész évben jelenlévő, változatos matricagyüjtő kampányukra. Ezek a kihelyezések mindig azon árucsoportok felett lógnak, amelyekre a hirdetés vonatkozik.

A szignifikanciavizsgálatok alapján elmondható, hogy az életkor mint háttérváltozó és a megszokás $(\mathrm{p}=0,007)$, a bolt közelsége $(\mathrm{p}=0,0 \mathrm{I2})$ és a jó kiszolgálás $(\mathrm{p}=0,038)$ között statisztikailag igazolt kapcsolat van. A 70-82 éves korosztály 50\%-a, az 50-59 éves korosztály $45 \%$-a, míg a fiatalok (30-39 évesek) több mint 1/3-a megszokásból, az 50-59 éves korosztály közel 90\%-a a közelség miatt vásárol a szupermarketben, míg az idősebb korosztály (60-82 évesek) a kiszolgálás magas színvonalát is figyelembe veszi. A boltválasztási szempontok közül az új kinézet az iskolai végzettséggel áll szignifikáns kapcsolatban $(\mathrm{p}=0,02 \mathrm{I})$. A középfokú 
végzettséggel rendelkezők (érettségi, technikus) több mint 40\%-a részesíti előnyben a szupermarket kinézetét üzletválasztása során. Továbbá szignifikáns kapcsolat mutatkozott a nem mint háttérváltozó és a kellemes légkör között $(\mathrm{p}=0,006)$, ahol a férfiak $2 \%$ a, a nők I 8\%-a számára fontos a komfortérzet.

A továbbiakban a vevői elégedettséget vizsgáltuk, elsőként a megfigyelés eredményeit mutatjuk be. Elöre meghatározott szempontrendszerü megfigyelésekkel feltérképeztük az üzlet minden szegletét. Számos vásárlóval kerültünk közvetlen kommunikációs kapcsolatba, ami hozzájárult az üzlet erősségeinek és gyengeségeinek megvilágításához.

A megfigyelés alapján a vásárlók szemmel láthatóan pozitív várakozással lépték át a szupermarket bejáratát. Elsősorban a szép, új környezet, valamint a nagy áruválaszték dominált megítélésükben, míg elégedetlenségüket leginkább a termékek nehézkes fellelhetőségében fejezték ki. Utóbbit több szituáció is alátámasztja. 20I6. december 2 -án, I 2 óra 42 perckor 60 év körüli hölgy egy árucikk keresésében kért segítséget. Ezzel egyidejűleg elmondta, hogy nagyon zsúfoltak a polcok és nehezen áttekinthetők. Az azonos árufajták sokszor nem lelhetők fel egymás mellett, hanem a rákövetkező sorban vannak.

Egy következő szituációban megszólítottuk a vevőt. Az 50-55 év körüli, szintén hölgy vásárló kérdése az volt, hogy nem tudjuke véletlenül, merre találhatók a teafélék. Látott kihelyezve különböző teákat egy állványon az egyik gondola végén, azonban ő nem azokból a fajtákból szeretett volna vásárolni. Miután tájékoztattuk, elmondta, hogy jó lenne, ha legalább a gondolák felett lenne tájékoztatótábla elhelyezve, hogy tudják, melyik sorban milyen termék található. $\mathrm{A} z$ idősebb vásárlókra jellemző volt némi elégedetlenség, de a negatív tapasztalások ellenére a megújult üzlettel elégedettek voltak. Az elégedettségre, hűségre vonatkozó kérdésünkben arra voltunk kíváncsiak, hogy alakul az irodalmi áttekintésben említett Aswad-ra (2012) hivatkozott Homburg-Stock-féle elégedettséglojalitás mátrix vásárlókra való alkalmazása. A vásárlói elégedettség és lojalitás mentén vizsgáltuk a I 59 fó válaszadót, akik négy állításból csak egyet választhattak. Ez alapján felállítottuk a SPARvevőkre vonatkozó elégedettség és lojalitás mátrixot (2. ábra). Az első csoportba az általunk „,ragaszkodók”-nak nevezettek tartoznak, akik partnerként müködnek együtt a kaposvári SPAR szupermarkettel. Nagyfokú elégedettségük és lojalitásuk 36,48\%-os részarányt képvisel. Előbbinél magasabb, 46,54\%-ot tesznek ki a viszonylag alkalomszerű vásárlással jellemezhető vásárlók. Ők a „keresgélők”, akiket a kíváncsiság is hajt, így magas elégedettséget, de alacsony lojalitást mutatnak, hiszen nemcsak a szupermarket nyújtotta lehetőségekkel szeretnének élni.

2. ábra: A SPAR szupermarket vevői elégedettség és lojalitás mátrixa $(\mathrm{n}=$ 159)

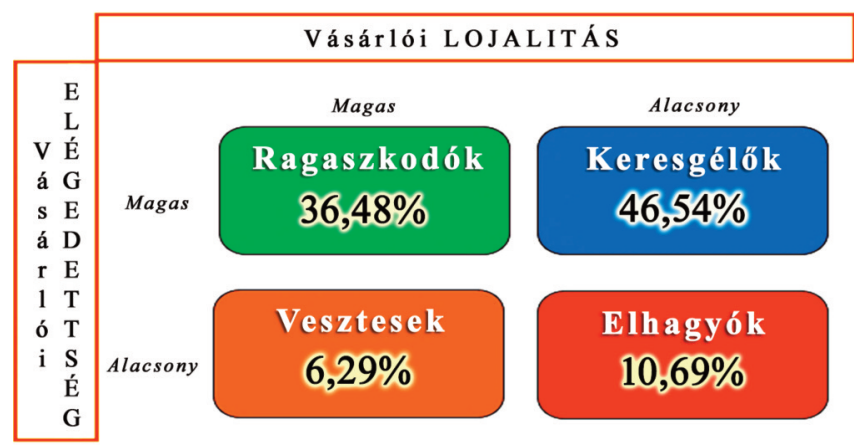

A következő csoportnál leginkább a kényszerűség tényéből fakad a vásárlói magatartás. Ezen fogyasztók mindössze 6,29\%kal foglalják el helyüket a mátrixban. Csak a SPAR szupermarketben költenek, így hüségük magas, mégis a „vesztes” kategóriába tartoznak kimagasló elégedetlenségükkel. Ez azzal magyarázható, hogy helyzetükből nem tudnak szabadulni, belenyugszanak a SPAR nyújtotta kínálatba. „Elhagyók”-ként említettük azokat a vevőket, akik a záró, negyedik helyet töltik be. Közel I I\%-ot tesznek ki, amely a I 59 fös mintából összesen I 7 föt takar. Hüségük és elégedettségük, így az újravásárlások száma is alacsony, s ennek alapján nem alakult ki bennük a szupermarkettel szembeni pozitív attitűd. A különböző kategóriákat összevontan - a ragaszkodókat és keresgélőket figyelembe véve - elemezve elmondható, hogy a vásárlók több mint $80 \%$-a elégedett a Sparral. Hüség szempontjából az alulreprezentáltság jellemzi a megkérdezett fogyasztókat.

További nem szignifikáns, de fontos jellemzők, hogy azok, akik azért a SPAR-ban vásárolnak, mert elégedettek vele, leginkább a 40-49 éves korosztályba tartoznak, közel 30\%-kal. A „vesztes” csoportot többnyire a 60-69 évesek képezik, vagyis ők nem képesek üzletváltásra, 50\%-nál van jelen a „röghöz kötöttség”. Ezenkívül az 50-59 éves korosztály minősül a „legkíváncsibbnak”, hiszen közel 2/3-uk keresgélőnek számít. Míg az „elhagyók” elnevezésű mátrixnegyedben a fiatalok (I 8-39 évesek) a meghatározóak. Iskolai végzettség tekintetében nem vonható le messzemenő következtetés, hiszen a legtöbb válaszadó diplomával és érettségivel rendelkezett, így ők képviselik a legmagasabb arányokat is. A jövedelmi helyzetet figyelembe véve elmondható, hogy a rosszabb anyagi helyzetben lévő fogyasztók azért „keresgélők”, mert az alacsonyabb ár, a vásárlásaik során a „mindig a legolcsóbb termékek” felkeresésének prioritása dominál. A magasabb bevétellel rendelkezők pedig valószínűsíthetően a minőség vagy a márka miatt járnak a SPAR szupermarketbe is vásárolni. A havonta befolyt források tekintetében kivételt képeznek a „ragaszkodók” kategóriába tartozó, elégedett és egyben hüséges vásárlók, ahol az átlagos jövedelmi helyzet dominál. Ök feltételezhetően egy adott minőséget keresnek elfogadható áron.

\section{KÖVETKEZTETÉSEK, JAVASLATOK}

Eredményeink alapján először hipotéziseinket értékeljük, majd megfogalmazzuk javaslatainkat.

Hi hipotézisünket, mely arra vonatkozott, hogy a vásárló számára az üzletválasztási szempontok közül a SPAR szupermarket esetében a legfontosabb tényező a kedvező ár-érték arány, részben elvetjük. Ezen véleményünket a kérdőíves megkérdezés és megfigyelés is alátámasztja:

+ Az elöre meghatározott 9 üzletválasztási szempont közül fontossági sorrendben a 3. helyen szerepel a termékek jó minősége és 5 . helyen a kedvező ár kifejezés, vagyis csak minden 3. válaszadó jelezte a jó minőséget, és csupán minden 5. megkérdezett számára volt fontos az ár. Az elsődleges üzletválasztási szempont a bolt közelsége volt a vevői válaszok alapján. Ebből következően a megokosodott fogyasztó tudatában és döntéshozatalában nem a kedvező ár és érték a meghatározó.

- Azonban tapasztalásaink és az olvasott szakirodalmak szerint nem hagyható figyelmen kívül a vásárlásösztönző eszközök vásárlókra gyakorolt hatása sem, hiszen van, aki kifejezetten egyetlen akció miatt tér be az adott kereskedelmi egységbe. 
Javaslat: A kedvező ár és a jó minőség erősítése a vásárlói tudatban, ezáltal az üzlet a tőle távolabb élők számára is kedvező választási alternatíva lehet.

$\mathrm{H}_{2}$ hipotézis alapján a vásárlók többsége elégedett a megújult SPAR szupermarkettel. Feltételezésünket teljes mértékben igazoltnak érezzük. Ezt támasztja alá az alábbi eredmény:

+ A Homburg-Stock-féle elégedettség-lojalitás mátrix vásárlókra való alkalmazása megmutatta, hogy a ragaszkodó $(36,48 \%)$ és a keresgélő $(46,54 \%)$ vásárlói csoportok a válaszadók több mint $80 \%$-át teszik ki elégedettség szempontjából.

Javaslatı: Célszerü lenne a keresgélőket tovább vizsgálni, és esetükben meghatározni a „keresgélés” mibenlétét.

Javaslat2: Hűségkártyára való figyelemfelhívással, az igénylőlap eladók általi ajánlásával, az igényléskori segítségnyújtással a keresgélők hüsége növekedhet.

A „ma vásárlója” minden apró részletre figyel, ami számára fontos, amit a SPAR-nak hatékonyan kell kielégíteni, mert csak így lesz elégedett a VEVŐ!

\section{5. ÖSSZEFOGLALÁS}

Manapság egy kereskedelmi egység megléte, a vásárlási folyamat tényszerűsége önmagában nem elegendő a vásárlók viselkedésének megértéséhez, mert a vevők nem csupán eltérő preferenciákkal rendelkeznek, hanem kritikusak, és elvárásaik folyamatosan nőnek. Mindezek megértésére 2016/17-es évben egy teljeskörüen átalakított kaposvári SPAR szupermarketben végeztünk vizsgálatokat, és célul tüztük ki a megújult üzlet vásárlókra gyakorolt hatásának átfogó megismerését. Kutatásunk során az élelmiszer-vásárlást meghatározó első pillért a főbb üzletválasztási szempontok és a vevői elégedettség alkották.

Az első benyomás, a közvetlen tapasztalat általi információk pozitívan hatottak az újranyitásnak köszönhetően. Majd amikor már egyre inkább megismerhetővé vált a kereskedelmi egység, egyre több nehézség, ugyanakkor pozitív kicsengésű élmény vette kezdetét, mind a vásárlás, mind a konkrét vizsgálatok lefolytatása által. A megfigyelés alátámasztotta a kérdőíves megkérdezést, hiszen a I 59 vásárló körében a szép, új kinézet mellett elsősorban a bolt közelsége és a megszokás uralkodtak legfőbb üzletválasztási tényezőkként. Előbbiek mögött és eltérő sorrendben helyezkedtek el az árak, a termékek minőségének fontossága.

A modernizált szupermarkettel kapcsolatban hol elégedettségüket és hűségüket, hol elégedetlenségüket fejezték ki. Azonban a Homburg-Stock-féle dolgozói elégedettség-lojalitás mátrix vásárlókra való alkalmazásának segítségével megállapítottuk, hogy a válaszadók több mint $80 \%$-a elégedett az üzlettel, és hüségüket a vevők 40\%-a igazolta. Mégis, annak érdekében, hogy bizonyos mértékủ hüség kialakuljon a fogyasztóban egy termék, egy üzlet iránt, azt elő kell segíteni, s az elégedettséget aztán folyamatosan fenn kell tudni tartani. Egy idő után már alábbhagy a várakozás, vágyódás és a vásárlások monoton körforgása, a megszokás bír kísérő jelleggel, amit a szupermarketnek marketingeszközökkel szükséges feloldania.

\section{IRODALOM}

(I) Agárdi, I. (20I0). Kereskedelmi marketing és menedzsment. Budapest: Akadémiai.
(2) Aswad, D. (20I2). Az értékinnováció kiterjesztése a belső és külső ügyfélelégedettségen alapuló lojalitásra. Doktori $(\mathrm{PhD})$ értekezés tézisei. Miskolc: Miskolci Egyetem. Forrás: http://midra.unimiskolc.hu/JaDoX_Portlets/documents/document_I4564_sectio n_6907.pdf

(3) Bátor, A. (2007). A vevőelégedettség és a lojalitás kapcsolata a kereskedelmi bankok szférájában a lakossági piacon. Sopron: Nyugat-Magyarországi Egyetem.

(4) Bohnné, K. K. (2005). Elégedett az ügyfél? Az ügyfélelégedettség elméleti és gyakorlati alapjai. Budapest: Public Press Kft.

(5) Bohnné, K. K. (2009). Ügyfél elégedettség: Kikre is számíthatunk? In B. P. (Szerk.), Marketing nélkül nem megy! (pp. I67-I78). Budapest: T. Bálint Kiadó.

(6) Bohnné, K. K. (20I2). Elégedett az ügyfél? Nyilatkozat az ATV Gagdasági műsorában a könyvről és az ügyfél elégedettség fontosságáról. Letöltés dátuma: 20I2, oI2. I8. Forrás: https: //www.youtube.com/watch? $v=j{ }_{9} V_{D D D}{ }_{2} \mathrm{fBk} \&$ feature $=$ youtu.be

(7) Földi, K. (2008). Üzletválasztást befolyásoló tényezők jelentősége az élelmiszer kiskereskedelemi horizontális versenyben. Szolnoki Tudományos Közlemények XII. Letöltés dátuma: 2017. 10. 04., forrás: htpp://tudomany.szolnokmtesz.hu/kulonszamok/2008/cikkek/foldi-katalin.pdf

(8) Földi, K. (20I2). A fogyasztói üzletválasztási döntések az élelmiszerorientált kiskereskedelemben. Doktori $(\mathrm{PhD})$ értekezés. Pécs: Pécsi Tudományegyetem.

(9) Gyenge, B. (2008). Fogyasztói üzletválasztás a hagyományos bolti élelmiszer-kiskereskedelemben. Gödöllő: Szent István Egyetem.

(io) Hoffmeister-Tóth, Á., Simon, J. \& Sajtos, L. (2003). Fogyasztói elégedettség. Budapest: Alinea Kiadó.

(II) Horváth, J. (2010). A beszerzési társulások szerepe a Déldunántúli régió élelmiszer kereskedelmében. Kaposvár: Kaposvári Egyetem.

(I2) Kandikó, J. (2009). Árpolitika: Vevő és eladó eredményes kompromisszuma. In P. Bíró (Szerk.), Marketing nélkül nem megy! (pp. 47-5I). Budapest: T. Bálint Kiadó.

(I3) Kenesei, Z. (20I7). A vevői elégedettség mérésének lehetőségei többdimenziós szemléletben. Statisztikai Szemle, I., 29-50.

(I4) Kotler, P. \& Keller, K. (2012). Marketingmenedzsment. Budapest: Akadémiai Kiadó.

(I5) Lehota, J. (200I). Marketingkutatás az agrárgazdaságban. Budapest: Mezőgazda Kiadó.

(I6) Molnár, D. (20I0). Empirikus kutatási módszerek a szervezetfejlesztésben. Humán Innovációs Szemle, I-2., 6I-72.

(I7) Nielsen, P. A. (20I6). Boltválasztás: A vásárlás legyen kellemes élmény. Letöltés dátuma: 2017.06. 23., forrás: htpp//www.nielsen.com/hu/hu/insights/new/2016/shoppertrends-study.html

(I8) Rudolfné, M. K. (2015). A fogyasztói magatartás és az elégedettség főbb tényezői a vendéglátásban. Doktori $(\mathrm{PhD})$ értekezés. Gödöllő: Szent István Egyetem.

(I9) Székely, G., Sipos, L. \& Losó, V. (2009). FMCG Marketing. Budapest: Aula Kiadó.

(20) Törőcsik, M. (I995). Kereskedelmi marketing. Budapest: Közgazdasági és Jogi Könyvkiadó.

(2I) Törőcsik, M. (2007). Vásárlói magatartás. Budapest: Akadémiai Kiadó.

(22) Törőcsik, M. (2016). A fogyasztói magatartás új tendenciái. Vezetéstudomány, 20, 19-25. Forrás: http://unipub.lib.uni.corvinus.hu/2325/I/VT2016nI9.pdf

(23) Veres, Z., Hoffmann, M. \& Kozák, Á. (2006). Bevezetés a piackutatásba. Budapest: Akadémiai Kiadó. 